\title{
Performance evaluation of a modified seed drill for row crop planting under rainfed farming conditions
}

\author{
Abdalla S. Abdalla ${ }^{1}$ Abdelkarim D. Elfadil ${ }^{1 *}$ and Mohamed R. Mohamed ${ }^{2}$ \\ ${ }^{1}$ Dept. of Agricultural Engineering, Faculty of Agricultural science, Universityof Gezira, Wadmedani \\ Minstryof Agriculture, Northern Kordofan State, Sudan \\ Corresponding author*: karimfadil [@] yahoo.com \\ Article Received: 22.08.17; Revised: 12.12.17; Published online: 31 December 2017.
}

\begin{abstract}
Increasing demand for the optimization of crop production necessitates the use of precision planting for both timeliness and subsequent field operations. This study was carried out at Almigrih to compare the performance of a modified seed drill (VISPA) with the conventional wide level disc (WLD) traditionally used for sowing in the rainfed subsector. Results showed that seed drill was $60 \%$ faster and efficient than the WLD, about $60 \%$ less fuel consumption. VISPA can save about half the sesame seeds consumed by the WLD at 5cm within row spacing. For sorghum, the VISPA gave the recommended population at $25 \mathrm{~cm}$ within row spacing while the WLD about $337 \%$ of the recommended.
\end{abstract}

Key Words: Seed drill, Rainfed farming, Sesame, Sorghum and Wide level disk

Cite Article: Abdalla, A. S., Elfadil, A. D. and Mohamed, M. R. (2017). Performance evaluation of a modified seed drill for row crop planting under rainfed farming conditions. Journal of Bioscience and Agriculture Research,16(01), 1301-1308.

Crossref: https://doi.org/10.18801/jbar.160117.161

Article distributed under terms of a Creative Common Attribution 4.0 International License.

\section{Introduction}

Increasing importance of timing for the vital cultural operations necessitates the gradual replacement of hand labor and animals by machinery, not only for such arduous tasks as land preparation, but also where labor bottlenecks occur in tasks such as planting (Pothecary, 1968). The main limiting factor for crop planting is the weather and soil conditions prevailing during the planting period. Heavy rainfall and adverse soil conditions are likely to cause time losses, and these are aggravated by the necessity for high standards of operation and supervision if planters are to operate efficiently. The purpose of most planters and drills (excluding broadcast planters) is to plant seeds evenly in rows or on beds (Breece et al., 1981). Abernathy and Porterfield (1969) reported that the principal functions of a planter are to open a furrow for the seed, meter seeds at the desired rate, placing seeds and fertilizer in the ground, cover and firm the soil around the seeds. 
Richey (1961) reported that the planters must accomplish the planting process without damaging the seeds, plant at the desired seed rate, place seeds uniformly distributed or in hills at the desired depth covering and compacting the soil as desired around the seed. Bainer et al. (1963) mentioned that the primary function of planting operation is to establish an optimum plant population and spacing, and that the ultimate goal is to obtain the maximum net return per acre. The mechanical planters are also required to apply fertilizers at the required rates, and place them at the proper position relative to the seeds or otherwise, manipulate the soil to provide anoptimum soil physical condition for seed germination and emergence. The Wide Level disk (WLD) is the dominant seeding implement for all crops under rain-fed subsector in the Sudan that is because it can perform the operations of weed control and sowing the seeds in one pass. In this case seeds are often placed too deep or too shallow thus causing variation in seed emergence, uneven and patchy stand. The broadcasted pattern of seeds lead to plant stand that is impossible to control weeds with an inter-row cultivator. Moreover, manual weeding of broadcasted plants usually results in decreasing the plant stand by unintentional weeding of some crop seedling and decreased the yield (Anonymous, 1988). Precision planters accurately place single seeds or groups of seeds almost equidistant apart along a furrow. They are typically used to plant crops that require accurate control of plant population, and spacing between and along the rows. Precision seed metering systems giving a precision drill, hill drop or check row planting pattern are used on this type of planting machine. But it is very complex and very expensive. This experiment was conducted to evaluate the performance of a locally modified seed drill for row crop planting under rain fed farming conditions.

\section{Materials and Methods}

Experimental site: The experiment was conducted during the rainy season 2012-2013at al Megrih, west of Gedarif town (Sudan).Two types of planting machines were used, a four-row drilling machine referred to as (VISPA), with an external flute type drilling mechanism, two hoppers, each with two metering units, anda wide level diskwith an external fluted seed metering wheels, seed box, disks gang and main frame, a chisel plow composed of long straight shanks, and double ended 6-cm wide shear points. Chisel shanks are mounted on a rectangular frame on two gangs seven shanks three front shanks and four shanks at the rear at spacing of $60 \mathrm{~cm}$ on each row. The shanks arranged in a zigzag pattern to give $30 \mathrm{~cm}$ spacing. The tillage depth was $10 \mathrm{~cm}$. The experiment layout was two factors randomized complete block design. The dimension of blocks was $\left(150 \times 21 \mathrm{~m}=3150 \mathrm{~m}^{2}\right)$. For the study of plant population three crops were selected and sown by the two machines. Sesame crop was used for further comparison between the two machines regarding plant height and bottom capsule height.

\section{Experimental method}

Planting: Sesame was sown on $25^{\text {th }}$ and $27^{\text {th }}$ of July, sunflower sown on the $1^{\text {st }}$ of August and sorghum was sown on the $4^{\text {th }}$ of August.

Operating speed: The machine speed was obtained using the following equation:

$$
\operatorname{speed}(\mathrm{km} / \mathrm{hr})=\left[\left(\frac{280 \mathrm{~m}}{\text { time in seconds to travel } 280 \mathrm{~m}}\right)\left(\frac{3600 \mathrm{sec} / \mathrm{hr}}{1000 \mathrm{~m} / \mathrm{km}}\right)\right] .
$$

Field capacity: The theoretical field capacity was calculated with the following equation: theoretical field capacity $\left(\frac{\mathrm{km}}{\mathrm{hr}}\right)=\frac{\mathrm{sw}}{\mathrm{c}}$

Where,

$$
\begin{array}{lll}
\mathrm{S} & =\quad \text { Forward speed of the seed drill }(\mathrm{km} / \mathrm{hr}) \\
\mathrm{W} & = & \text { The operating width of the drill }(\mathrm{m})
\end{array}
$$

The same equation of the theoretical capacity was used to measure the actual field capacity by multiplying by the actual machine width.

Fuel consumption measurements: The fuel consumption was measured by filling the tank with fuel then operating the land with each of the tested planters. At the end of the task the fuel tank was refilled to estimate the corresponding fuel consumption. 
Plant population: For counting the plant population for the WLD, twenty random samples were taken after four weeks, by throwing the square rectangular frame at random, and then the plants within the frame area were counted.

Spacing between plants (VISPA): A metal tape was used for measuring within row spacing between plants for the VISPA hundred consecutive spacing were measured. Lines were randomly picked. Four replications were taken. Measurements were taken after four weeks from germination.

Plant height: Measurements were conducted when the crop was at full maturity and before harvesting.

Bottom capsule height: Measurements of bottom capsule height from ground for sesame and capsule zone were taken using a metal tape. Twenty random readings for each plot were taken. These measurements were conducted simultaneously with total plant height measurements.

\section{Results and Discussion}

\section{Machine field parameters}

Table 01 contains the specifications of the two machines and their field capacity, field efficiency and fuel consumption. Regarding the measured parameters, VISPA was better than the WLD. VISPA was found to be about $69 \%$ faster and efficient in field coverage, the machine is easy to maneuver and by nature it works in a continuous pattern, therefore, the time efficiency was found to be $94 \%$ as compared to $72 \%$ for the WLD. As fuel consumption per hectare, WLD was found to consume about $60 \%$ more than the fuel consumed by VISPA.VISPA can be considered as a minimum or zero tillage planter, therefor, this result agreed with Rawat et al. (2006) who stated that the zero tillage sowing was found to be most time (88\%) and energy (79\%) efficient as compared to conventional method of sowing. The zero tillage sowing was more economical (79\%) in comparison to conventional method.

Table 01. Seed drills measured parameters

\begin{tabular}{lll}
\hline Machine parameters & VISPA & WLD \\
\hline Theoretical working width (m) & 3.20 & 4.14 \\
Effective working width (m) & 3.20 & 3.00 \\
Speed (km/hr) & 11.80 & 7.00 \\
field capacity (ha/hr) & 3.54 & 2.11 \\
Efficiency (\%) & 94.00 & 72.00 \\
Fuel consumption (l/ha) & 2.98 & 4.76 \\
\hline
\end{tabular}

\section{Plant population}

\section{Sesame}

The seeding performance was measured after the emergence of seeds, thereafter; seeding count was measured for assessment of plant population. Hajo (2005) reported that the recommended plant population for sesame is 220 thousand plant/ha $\left(22 \mathrm{plant} / \mathrm{m}^{2}\right)$. The actual population for the three settings for VISPA (5, 7.5 and $10 \mathrm{~cm}$ within row spacing) and for the control (WLD). The results for sesame gave 18,13, 11 for VISPA and 42 for WLD plant $/ \mathrm{m}^{2}$ with corresponding spacing for (VISPA) of 7, 10 and $11 \mathrm{~cm}$ for spacing $5,7.5$ and $10 \mathrm{~cm}$ respectively (Table 02). The populations percentages were 81, 57, 52 and 191\% for VISPA (5, 7.5 and $10 \mathrm{~cm}$ ) and WLD, as compared to the recommended, respectively (Table 03).

This result indicated that VISPA can save about half of the seeds at setting $5 \mathrm{~cm}$, with acceptable within row distribution and overall population of sesame, rows can allow inter-row cultivation or easy and higher efficiency of manual weeding. This result agreed with Weiss (1971), who stated the superiority of row planting over broadcasting. 
Table 02. Average plant population $/ \mathrm{m}^{2}$ of sesame crop for seed drill

\begin{tabular}{|c|c|c|c|c|}
\hline Seed drill & \multicolumn{2}{|c|}{ Spacing between plants $(\mathrm{cm})$} & \multicolumn{2}{|c|}{ Plant population $/ \mathrm{m}^{2}$} \\
\hline \multirow{4}{*}{ VISPA } & Theoretical & Actual & Theoretical & Actual \\
\hline & $5 \mathrm{~cm}$ & $7 \mathrm{~cm}$ & 25 & 18 \\
\hline & $7.5 \mathrm{~cm}$ & $10 \mathrm{~cm}$ & 17 & 13 \\
\hline & $10 \mathrm{~cm}$ & $11 \mathrm{~cm}$ & 13 & 11 \\
\hline
\end{tabular}

Table 03. Total plant population of sesame

\begin{tabular}{llllll}
\hline Seed drills & \multicolumn{2}{c}{ Plant population per ha } & & \\
& $\begin{array}{l}\text { Theoretical } \\
\text { (Calculated) }\end{array}$ & $\begin{array}{l}\text { Actual } \\
\text { Calculated }\end{array}$ & $\begin{array}{l}\text { \%from } \\
\text { theoretical }\end{array}$ & recommended & $\begin{array}{l}\text { \%from } \\
\text { recommended }\end{array}$ \\
\hline VISPA(5cm) & 250000 & 178600 & 71 & 220000 & 81 \\
VISPA(7.5cm) & 166667 & 125000 & 75 & 220000 & 57 \\
VISPA $(10 \mathrm{~cm})$ & 125000 & 113600 & 90 & 220000 & 52 \\
WLD & & 420000 & & 220000 & 191 \\
\hline
\end{tabular}

\section{Within row spacing}

The results of spacing between plants for VISPA planter was estimated by measuring 100 plants. Means of the treatments resulted in $7 \mathrm{~cm}, 10 \mathrm{~cm}$ and $11 \mathrm{~cm}$ for spacing setting of $5,7.5$ and $10 \mathrm{~cm}$ respectively. Setting $10 \mathrm{~cm}$, resulted in better spacing accuracy (90\%) as compared to spacing $5 \mathrm{~cm}$ $(71 \%)$ and spacing $7.5 \mathrm{~cm}(75 \%)$. Table 04 showed results of analysis of variance for spacing between plants. It showed an inverse relation between plant spacing and C.V.

Table 04. Analysis of variance for spacing between plants in sesame by VISPA

\begin{tabular}{lll}
\hline Spacing setting $(\mathrm{cm})$ & SE & C.V \\
\hline VISPA $5 \mathrm{~cm}$ & 1.27 & $29.98 \%$ \\
VISPA $7.5 \mathrm{~cm}$ & 1.05 & $17.67 \%$ \\
VISPA $10 \mathrm{~cm}$ & 0.67 & $10.19 \%$ \\
\hline
\end{tabular}

\section{Sorghum}

Hajo (2005) reported that the recommended plant population for sorghum is 130 thousand plant/ha (13 plant $/ \mathrm{m}^{2}$ ). The results gave 16, 13, 9 for VISPA and 45 for WLD plant $/ \mathrm{m}^{2}$ with corresponding spacing for (VISPA) of 8, 10 and $14 \mathrm{~cm}$ for spacing $5,7.5$ and $10 \mathrm{~cm}$ respectively (Table 05). Table 06 shows that the populations percentages were $117,93,66$ and $337 \%$ for VISPA $(5,7.5$ and $10 \mathrm{~cm})$ and WLD, as compared to the recommended respectively. Setting $7.5 \mathrm{~cm}$ agreed exactly with the recommended population of 13 plants $/ \mathrm{m}^{2}$. Using the WLD found to consume a considerable amount of seeds (about four times the recommended). Result for VISPA showed plant population more or less three plants than recommended for $5 \mathrm{~cm}, 10 \mathrm{~cm}$ and within recommended for $7.5 \mathrm{~cm}$ spacing between plants, and give good distributed stand than WLD. As in row spacing can allow inter-row cultivation or easy and higher efficiency of manual weeding.

Table 05. Average plant population $/ \mathrm{m}^{2}$ of Sorghum

\begin{tabular}{lllll}
\hline Seed drill & \multicolumn{2}{l}{ Spacing between plant $(\mathrm{cm})$} & \multicolumn{2}{l}{ Average plant population $/ \mathrm{m}^{2}$} \\
\cline { 2 - 5 } & Theoretical spacing & Actual spacing & Theoretical & Actual \\
\hline VISPA & $5 \mathrm{~cm}$ & $8 \mathrm{~cm}$ & 25 & 16 \\
& $7.5 \mathrm{~cm}$ & $10 \mathrm{~cm}$ & 17 & 13 \\
& $10 \mathrm{~cm}$ & $14 \mathrm{~cm}$ & 13 & 9 \\
WLD & & & & 45 \\
\hline
\end{tabular}


Table 06. Total plant population of sorghum

\begin{tabular}{llllll}
\hline Seed drills & \multicolumn{5}{c}{ Plant population per fed an to sorghum } \\
\cline { 2 - 5 } & Theoretical & Actual & $\begin{array}{l}\text { \%from } \\
\text { theoretical }\end{array}$ & Recommended & $\begin{array}{l}\text { \%from } \\
\text { recommended }\end{array}$ \\
\hline VISPA $(5 \mathrm{~cm})$ & 250000 & 156250 & 63 & 133333 & 117 \\
VISPA $(7.5 \mathrm{~cm})$ & 166667 & 125000 & 75 & 133333 & 93 \\
VISPA $(10 \mathrm{~cm})$ & 125000 & 89285 & 71 & 133333 & 66 \\
WLD & & 450000 & & 337 \\
\hline
\end{tabular}

Table 07. Analysis of variance for spacing between plants in sorghum by VISPA

\begin{tabular}{lll}
\hline Spacing between plants $(\mathrm{cm})$ & SE & C.V \\
\hline VISPA $5 \mathrm{~cm}$ & 0.87 & $20.27 \%$ \\
VISPA $7.5 \mathrm{~cm}$ & 2 & $34.04 \%$ \\
VISPA $10 \mathrm{~cm}$ & 1.48 & $17.66 \%$ \\
\hline
\end{tabular}

\section{Within row spacing}

Means of the treatments resulted in $8 \mathrm{~cm}, 10 \mathrm{~cm}$ and $14 \mathrm{~cm}$ for spacing setting of $5,7.5$ and 10 respectively. Setting $7.5 \mathrm{~cm}$ resulted in better spacing accuracy $(75 \%)$ as compared to spacing $5 \mathrm{~cm}(63 \%)$ and spacing $10 \mathrm{~cm}(71 \%)$. Table 07 showed results of analysis of variance for spacing between plants. It showed an inverse relation between plant spacing and C.V.

\section{Sunflower}

Tajuldin (2005) reported that the recommended plant population for sunflower is 15 thousand plants/fed. (4 plant $/ \mathrm{m}^{2}$ ). Table 08 and 09 and Figure 03 showed the expected and the actual population for the three settings for VISPA(20, 25 and $33 \mathrm{~cm}$ within row spacing). Results showed 7, 4 and 3 plants $/ \mathrm{m}^{2}$ for spacing 20,25 and $33 \mathrm{~cm}$ respectively, with corresponding average spacing of 18 , 28 and $35 \mathrm{~cm}$. The resulted spacings were within the range of the expected 20,25 and $33 \mathrm{~cm}$. The metering mechanism accuracy was found to be directly related to seed size; the larger the seed the more accurate is the metering device. The percent of plant population as compared to the recommended showed that although spacing $20 \mathrm{~cm}$ expected to give $(175 \%)$ however, it resulted in (194\%) while spacing 25 and $33 \mathrm{~cm}$ resulted in (125\%) and (100\%) respectively.

The analysis of variance showed significant different $(\mathrm{p}=0.05)$ for plant population per square meter between three spacing. Results which is nearly double the recommended population $(194 \%)$ for $20 \mathrm{~cm}$ and within recommended for $(25 \mathrm{~cm}$ and $33 \mathrm{~cm}$ spacing between plants). VISPA give good distributed in row spacing can allow inter-row cultivation or easy and higher efficiency of manual weeding.

Table 08. Average plant population $/ \mathrm{m}^{2}$ of Sunflower by VISPA

\begin{tabular}{lllll}
\hline Seed drill & \multicolumn{2}{l}{ Spacing between plant $(\mathrm{cm})$} & \multicolumn{2}{l}{ Average plant population $/ \mathrm{m}^{2}$} \\
\cline { 2 - 5 } & Theoretical spacing & Actual spacing & Theoretical & Actual \\
\hline VISPA & $20 \mathrm{~cm}$ & $18 \mathrm{~cm}$ & 6 & 7 \\
& $25 \mathrm{~cm}$ & $28 \mathrm{~cm}$ & 5 & 4 \\
& $33 \mathrm{~cm}$ & $35 \mathrm{~cm}$ & 4 & 3 \\
\hline
\end{tabular}

Table 09. Total plant population/fed of sunflower

\begin{tabular}{llllll}
\hline Seed drill & \multicolumn{5}{c}{ Plant population per fedan } \\
\cline { 2 - 6 } & $\begin{array}{l}\text { Theoretical } \\
\text { population }\end{array}$ & $\begin{array}{l}\text { Actual } \\
\text { population }\end{array}$ & $\begin{array}{l}\text { \%from } \\
\text { theoretical }\end{array}$ & Recommended & $\begin{array}{l}\text { \% from } \\
\text { recommended }\end{array}$ \\
\hline VISPA20cm & 62500 & 69440 & 111 & 35700 & 194 \\
VISPA25cm & 50000 & 44640 & 89 & 35700 & 125 \\
VISPA33cm & 37850 & 35700 & 94 & 35700 & 1.00 \\
\hline
\end{tabular}




\section{Within rowpacing}

Means of the treatments resulted in $18 \mathrm{~cm}, 28 \mathrm{~cm}$ and $35 \mathrm{~cm}$ for spacing setting of 20,25 and 33 respectively. Setting $20 \mathrm{~cm}$, resulted in better spacing accuracy $(111 \%)$ as compared to spacing $33 \mathrm{~cm}$ $(94 \%)$ and spacing $25 \mathrm{~cm}(89 \%)$ ). Table 10 showed results of analysis of variance for spacing between plants. It showed an inverse relation between plant spacing and C.V.

Table 10. Analysis of variance for spacing between plants in sunflower by VISPA

\begin{tabular}{lcc}
\hline \multicolumn{1}{c}{ Spacing between plants } & SE & C.V $(\%)$ \\
\hline VISPA $(20 \mathrm{~cm})$ & 3.35 & 31.65 \\
VISPA $(25 \mathrm{~cm})$ & 2.84 & 18.17 \\
VISPA $(33 \mathrm{~cm})$ & 4.26 & 21.15 \\
\hline
\end{tabular}

Table 11. Plants population/fed for VISPA

\begin{tabular}{|c|c|c|c|c|}
\hline \multirow[t]{2}{*}{ Crops } & \multicolumn{3}{|c|}{ Spacing between plants } & \multirow[t]{2}{*}{ Fluctuation } \\
\hline & $5 \mathrm{~cm}$ & $7.5 \mathrm{~cm}$ & $10 \mathrm{~cm}$ & \\
\hline Sesame (\%from recommended) & 80 & 56 & 51 & 62 \\
\hline \multirow[t]{3}{*}{ Sorghum (\%from recommended) } & 117 & 93 & 66 & 92 \\
\hline & \multicolumn{3}{|c|}{ Spacing between plants } & \\
\hline & $20 \mathrm{~cm}$ & $25 \mathrm{~cm}$ & $33 \mathrm{~cm}$ & \\
\hline Sunflower (\%from recommended) & 194 & 125 & 100 & 139 \\
\hline
\end{tabular}

\section{Plant Parameters (Sesame)}

\section{Total plant height}

Figure 01 showed the results of plant height. For VISPA the plant height was found to be 118, 111, 126 and $90 \mathrm{~cm}$ for spacings $5,7.5,10 \mathrm{~cm}$ and the WLD cmrespectively. The analysis of variance showed no significant different between the results of the treatment. However, row planting resulted in higher plants as compared to all results showed plant heights more than the critical height of broadcasting. $70 \mathrm{~cm}$ plant height was found to be the minimum height for using mechanical reapers (Elebaid, 2011). This result agreed with (Langham et al., 2006) under high moisture conditions, sesame plant can reach 1.3- $2.0 \mathrm{~m}$ in height. In dry land conditions, it is generally $1.0-1.7 \mathrm{~m}$, depending on rain.

\section{Bottom capsule height}

Results of bottom capsule height for the spacing $5 \mathrm{~cm}, 7.5 \mathrm{~cm}$ and $10 \mathrm{~cm}$ were shown in Figure 02 . Bottom capsule height were found to be $51 \mathrm{~cm}, 57 \mathrm{~cm}$ and $55 \mathrm{~cm}$ for spacings $5,7.5$ and $10 \mathrm{~cm}$ respectively, while the wide level disk resulted in $57 \mathrm{~cm}$. Analysis of variance showed no significant differences on bottom capsules height for the different treatments.

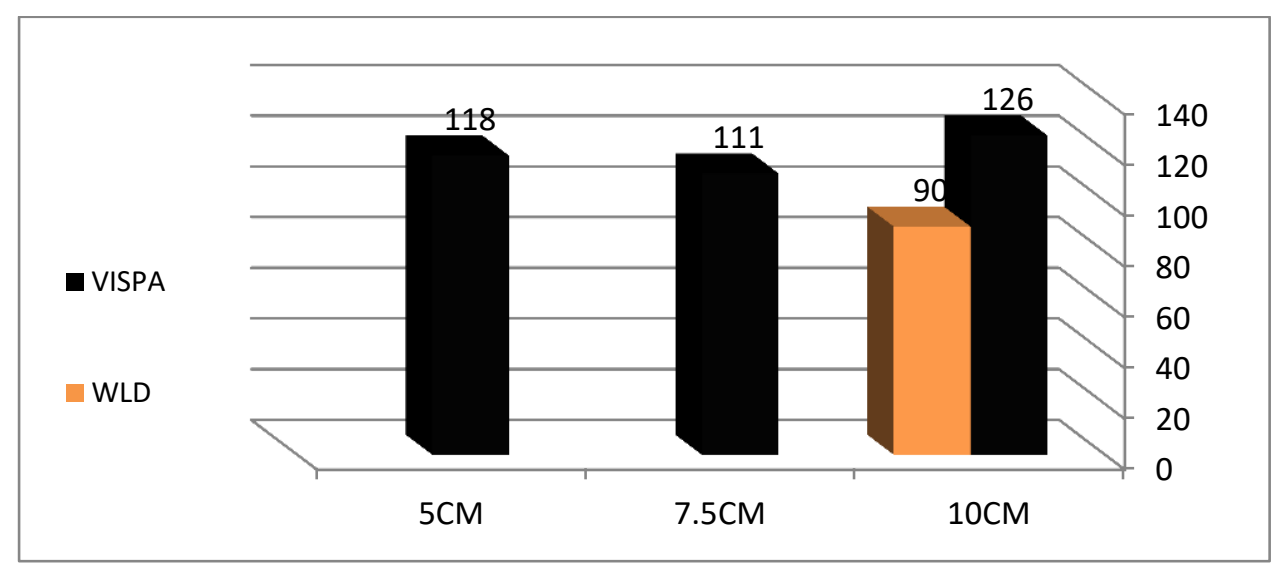

Figure 01. Average plant height of sesame for the VISPA and WLD. 


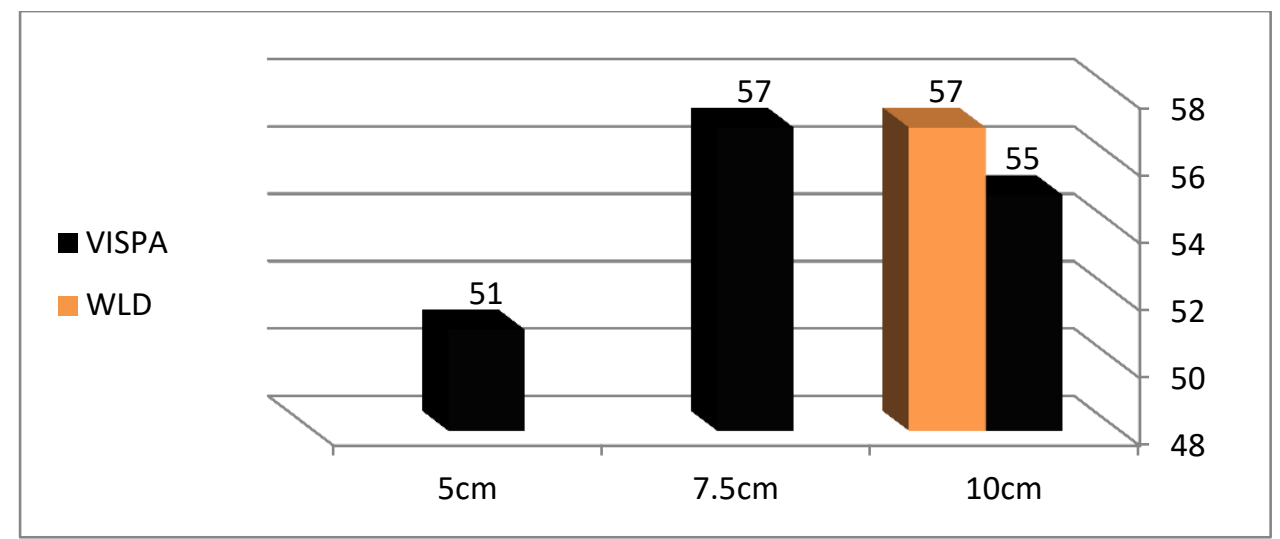

Figure 02. Average capsule height by VISPA and(WLD).

\section{Number of branches}

The number of branches per plant was found to be four branches for the spacing $5 \mathrm{~cm}$, three branches for both 7.5 and $10 \mathrm{~cm}$ spacing, while the branching for the WLD was only two branches per plant.

\section{Number of capsule per plant}

The numbers of capsule per plant were 40,26 and 30 for the spacing $5 \mathrm{~cm}, 7.5 \mathrm{~cm}$ and $10 \mathrm{~cm}$ respectively. While number of capsule for the WLD was only 17 capsules. The analysis of variance showed no significant difference between the two seed drills. However VISPA resulted in higher number of capsules than WLD for all spacings. This was due to the fact that capsules setting started at the same height but row plants resulted in taller plants and of more branches as compare to broadcasting by the WLD of to the number of branches.

\section{Conclusion}

The wide level disk suffers from uneven seed distribution and produced highesr plant population, while VISPA produced plant population within the recommended range and can save $50 \%$ of the seed compared to the WLD. Fuel consumption, field efficiency and effective field capacity were significantly improved by VISPA.

\section{References}

[1]. Abernathy, G. H. and Porterfield, J. G. (1969). Effect of planter opener shape on furrow characteristics. Journal of Agricultural Engineering, St. Joseph, Michigan, U.S.A. 12 (1), 16.

[2]. Anonymous (1988). Sudan-Canada Mechanized Dryland Farming Project, 1988 Annual Report, Appendix, Volume II.

[3]. Bainer, R., A. R. Kepener and Barger, E. L. (1963). Principles of Farm Machinery. $3^{\text {rd }}$ Edition. John Wiley and Sons, Inc., New York, London.

[4]. Breece, H. E., Harsen, H. V. and Hoener, T. A. (1981). Fundamentals of Machine Operation: Planting. Deere and Company, Moline, Illinois, U.S.A.

[5]. Elebaid, J. I. (2011). Performance evaluation of the self-propelled sesame cutter-binder under gedarif farming conditions, Gedarif State, Sudan. Unpublished M. SC. Thesis university of Gezira. Sudan.

[6]. Hago, T. M. (2005). Field Crops in Sudan. Sudan Open University Printing Press

[7]. Langham, D. R., G. Smith, T. Wiemers, and Riney, J. (2006). Sesame Growers Pamphlet. Sesaco Corporation. Lubbck. San Antanio. Texas.

[8]. Pothecary, B. P. (1968). A guide to the Mechanization of Agriculture in the Sudan Gezira Scheme. Sudan Gezira Board, Barakat, Sudan.

[9]. Rawat, S. N and Varma, M. R. (2006). Performance evaluation of zero-till fertilizer seed-drill for wheat crop. Karnataka Journal of Agricultural Sciences, 19(2), 348-351.

[10]. Richey, C. B. (1961). Seeding and Planting Machines. Agricultural Engineering Handbook. McGraw -Hill Book Company, Inc., New York, Toronto, London. 
[11]. Tajuldin, M. H. (2005). Field crops in Sudan. Sudan Open University.

[12]. Weiss, E. A. (1971). Castor, Sesame and Safflower. Leonard Hill Books, London. pp. 311-525.

\section{HOW TO CITE THIS ARTICLE?}

\section{Crossref: https://doi.org/10.18801/jbar.160117.161}

\section{APA (American Psychological Association)}

Abdalla, A. S., Elfadil, A. D. and Mohamed, M. R. (2017). Performance evaluation of a modified seed drill for row crop plantingunder rainfed farming conditions. Journal of Bioscience and Agriculture Research,16(01), 1301-1308.

\section{MLA (Modern Language Association)}

Abdalla, A. S., Elfadil, A. D. and Mohamed, M. R. "Performance evaluation of a modified seed drill for row crop plantingunder rainfed farming conditions". Journal of Bioscience and Agriculture Research, 16.01(2017): 1301-1300.

\section{Chicago and or Turabian}

Abdalla, A. S., Elfadil, A. D. and Mohamed, M. R. "Performance evaluation of a modified seed drill for row crop plantingunder rainfed farming conditions". Journal of Bioscience and Agriculture Research,16 no.01(2017):1301-1308.

\section{Journal BiNET | Scientific Publication}

$\checkmark \quad$ Faster processing \& peer review

$\checkmark$ International editorial board

$\checkmark \quad 29$ business days publication

$\checkmark \quad$ Greater audience readership

$\checkmark \quad$ Indexing \&bibliographic integration

$\checkmark \quad$ Social sharing enabled

Submissionor email to submit@journalbinet.com

www.journalbinet.com/article-submission-form.htm 